\title{
Towards a gender-aware understanding of innovation: a three-dimensional route
}

Johanna Nählinder, Malin Tillmar and Caroline Wigren

The self-archived postprint version of this journal article is available at Linköping University Institutional Repository (DiVA):

http://urn.kb.se/resolve?urn=urn:nbn:se:liu:diva-118584

N.B.: When citing this work, cite the original publication.

Nählinder, J., Tillmar, M., Wigren, C., (2015), Towards a gender-aware understanding of innovation: a three-dimensional route, International Journal of Gender and Entrepreneurship, 7(1), 66-86.

https://doi.org/10.1108/IJGE-09-2012-0051

Original publication available at:

https://doi.org/10.1108/IJGE-09-2012-0051

Copyright: Emerald

http://www.emeraldinsight.com/ 


\title{
Towards a gender-aware understanding of innovation: a three-dimensional route
}

\author{
Johanna Nählinder and Malin Tillmar \\ Linköpings Universitet, Linköping, Sweden, and \\ Caroline Wigren \\ Lunds Universitet, Lund, Sweden
}

\begin{abstract}
Purpose - The purpose of this study is to discuss the theory of gender bias in innovation studies, to illustrate the gender bias of innovation studies by using empirical means and to suggest what is needed to reduce such bias. Previous studies on innovation have primarily focussed on male-dominated industries. These studies have been biased and hence unable to capture the range of innovations covered by theoretical definitions.
\end{abstract}

Design/methodology/approach - An innovation survey was conducted among entrepreneurs in the traditionally "female-labelled" health-care industry, avoiding the "male-labelled" concept of innovation itself in the questionnaire. The authors endeavoured to ascertain whether there is a significant difference between males and females in terms of innovativeness. Quantitative analyses were used to analyse the results and draw comparisons with an ordinary innovation survey.

Findings - Using a gender-aware operationalisation of innovation, no significant difference in innovativeness was found between men and women. This suggests that more attention is needed to correct the prevailing gender bias in innovation studies. A research model is presented to further understand the gender-biased operationalisations of innovation. Each of its three dimensions has a clear impact upon perceived innovativeness: the gender-label of the sector studied, the gender-neutrality of the operationalisation used in the study and the gender of the actors involved. All dimensions should be taken into account in future innovation studies that aim for gender neutrality.

Practical implications - Operationalisations for measuring innovations are usually biased. Therefore, women appear less innovative, which, in turn, leads to less visibility.

Originality/value - Gender perspectives are very seldom employed in innovation studies. In quantitative studies of this sort, it is even rarer. Our empirical evidence from the quantitative study 
shows the urgency of the need to broaden the concept both in academic, political and public debates.

This is not the least for efficiency reasons in resource allocation and public policy.

Keywords Innovation, Gender theory, Women's entrepreneurship, CIS, Services industries

Paper type Research paper

\section{Introduction}

It is still a commonly held belief that innovations are made of metal (cf. Utbult, 2007), or are at least technological and product-driven (Blake and Hanson, 2005). There is an obvious risk that such bias may cause the economy to miss out on the many advantages of innovation that we fail to even perceive, let alone encourage and support. In the so-called "innovation-driven economies" (Kelley et al., 2012) of many Western countries economic growth, to a large extent, takes place in the service sectors. Innovation research has traditionally focussed on the manufacturing sectors, leaving little attention to innovations and innovativeness in private- (cf. Gallouj and Weinstein, 1997; Barras, 1986; Miles, 2005) and public- (Mulgan, 2007; Windrum and Koch, 2008; Earl, 2002; Potts and Kastelle, 2010) service sectors. Lately, there has been a promising increased interest in studies of innovation in these sectors (cf. Windrum and Koch, 2008; Elg and Kollberg, 2009). However, service innovations are not commonly included in mainstream innovation surveys (cf. the European Community Innovation Survey [CIS], and also the Canadian innovation survey, SIBS, and its USA equivalent, BROS). A consequence of this focus on manufacturing sectors is that it makes men appear to be more innovative than women (Ljunggren et al., 2010). In this paper, we take the internationally influential CIS as a case in point.

Applying a gender perspective on innovation gives rise to certain theoretical implications (Fogelberg, 2013). In this paper, these are illustrated by first conducting an analysis of the CIS, and second by analysing our own survey in the traditionally "female-labelled" health-care sector[1].

There is a need to delve deeper into the gender labelling of innovation from both a theoretical and a practical perspective. There remains a lack of theoretical studies that problematise and discuss the different dimensions of gender labelling with respect to innovation. Furthermore, empirical studies that have attempted to capture innovativeness in female gender-labelled industries are rare. This article contributes to this nascent field of theoretical knowledge by conceptualising the genderedunderstanding 
of innovation in terms of three dimensions, and by revealing previous

gender-biases by employing a quantitative empirical study.

As indicated above, a new body of literature on gender and innovation is currently emerging (cf Alsos et al., 2013). One of the relatively early studies in this field was conducted by Nyberg (2009), who suggests that women's innovations are made invisible due to the male gender labelling of innovation as a concept, and its links to technology.

Kvidal and Ljunggren (2010), Ljunggren et al. (2010), Amble (2010) and Lindberg (2010) have drawn similar conclusions. However, the discussions presented in these studies have not yet made a significant impact on either mainstream innovation studies or the policy discussion surrounding important instruments of innovation measurement, such as the Oslo Manual (OECD, 2005) and the CIS (cf. Eurostat, 2008).

The aims of this paper are:

- to discuss the theory of gender bias in innovation studies;

- to illustrate the gender bias of innovation studies by using empirical means; and

- to suggest what is needed to reduce such bias.

To achieve these aims, we pose the following research questions:

$R Q 1$. Which industries have dominated in previous studies of men's and women's innovativeness?

$R Q 2$. What are the gendered consequences of previous operationalisations of innovation?

$R Q 3$. Does a gender-aware operationalisation combined with a focus on femalelabelled industries still indicate significant differences between men and women's innovativeness?

This research was conducted using an abductive approach (Alvesson and Sköldberg, 2000) where theoretical and empirical work is conducted interchangeably, one providing input to the other. For reasons of clarity, the article is structured as follows: $R Q 1$ and $R Q 2$ are discussed in the literature review, which follows below. The theoretical arguments are illustrated and supported, first by a section analysing CIS from a gender perspective and, subsequently, by our own telephone survey, which follows the literature review. A methodology description precedes the presentation of our results. The discussion section explicitly addresses the aim of the article and the research questions, before outlining a tentative model for gender-aware studies of innovation. The paper concludes with the study's implications for theory and practice. 


\section{Previous studies}

In this section, previous studies with implications for the gendering of innovation are reviewed and discussed in relation to the research questions listed above.

\section{Models and definitions of innovation}

Researchers of innovation and gender argue that the concepts innovation and innovators build on notions that promote men and certain forms of masculinity as the norm (cf. Blake and Hanson, 2005; Pettersson, 2007; Nyberg, 2009; Lindberg, 2010). Why this is the case can be explained in different ways. One explanation can be found in the dominance of the linear model of innovation, which was the first theoretical framework for understanding the relationship between science, technology and the economy (Godin, 2006). As Godin (ibid) also notes, the model has continued to feed public discourse and academic analyses, despite having been long criticised by not only, for example, Kline and Rosenberg (1986), but also by Schmookler (1966), Price and Bass (1969) and Meyers and Marquis (1969). In the linear model, innovation is regarded as a result of basic research, applied research, development, production and diffusion, which all take place in a chronological and sequential order. $R \& D$ has become a proxy for measuring innovation and, thereby, a "rhetorical entity" (Godin, 2006, p. 659) used by administrators and agencies that fund R\&D. Allowing R\&D to become a proxy for innovation is problematic, as all firms $\mathrm{d}$ o $\mathrm{n}$ ot $\mathrm{c}$ onduct $\mathrm{R} \& \mathrm{D}$. F or e xample, in knowledge-intensive service sectors, only 44 per cent of the innovative firms that were surveyed actually conducted R\&D (Nählinder, 2005). This implies that R\&D is thus an especially poor proxy for innovation in service sectors. Note too that female employment is concentrated in the service sector (Salazar and Holbrook, 2004) and if those sectors do not conduct R\&D females are overlooked.

Among those who, without success, have tried to replace the linear model are Kline (1985), Kline and Rosenberg (1986) and Rothwell (1992). Kline and Rosenberg (1986) argue that the linear model only holds for a minority of innovations, as innovations are not results of a linear chain of causation. According to them, firms innovate because they see a commercial need for it; their starting point is using knowledge they already possess in a novel way. When firms do not manage, the authors argue, the firms consider investing in scientific research. Consequently, it is the customer who is an experienced user and who is the source of innovation. This point is also stressed by von Hippel (1988) and Lundvall (1988). 
The resilience of the linear model is surprising against the backdrop of how innovation is defined in current research. See, for example, The Oxford Handbook of Innovation edited by Fagerberg et al. (2005). In this influential book, the authors argue that the linear model is only applicable to a minority of innovations. Today, there are several inclusive definitions of innovation. One definition is made by Kanter $(2000$, p. 168): "the creation and exploitation of ideas". This definition can, however, be criticised for being too vague. The 1997 Oslo Manual (OECD, 1997), in contrast, differentiates between "process innovation" (when goods or services can be produced with fewer resources); "product innovation" (the improvement or development of a new product, goods or services); and "organizational innovations" (new forms of organisation). Edquist et al. (2001) suggest that process innovations should be further divided into "technological process innovations" and "organizational process innovations" so as to facilitate analytical distinctions. Here, we use the inclusive definition provided in the Oxford Handbook of Innovation; "Invention is the first occurrence of an idea for a new product or process, while innovation is the first attempt to carry it out into practice" (Fagerberg et al., 2005, p. 4). This definition distinguishes between two requirements, both of which must be fulfilled for a specific change to be regarded as an innovation. The first requirement is the first occurrence of an idea. The second requirement is that this idea is put into practice, in one way or another. It should be noted that the definition does not include connotations of whether the products are goods or services, nor in which sector, industry or organisational form they are carried out. Hence, we argue that these inclusive definitions are not gender-biased as such. As we will see, it is the operationalisation of innovation that is often considerably more restrictive.

Three additional themes have been identified in the review of the emerging body of literature on innovation and gender: men and women as innovators, the operationalisation of innovation and the industries that are studied. Below, these are discussed in turn.

Men and women as innovators

Consistent with Kvidal and Ljunggren (2010), innovation processes are considered to be gender neutral. A plausible reason for this claim is that mainstream innovation studies seldom focus on the person, i.e. the innovator. However, women are still marginalised and are less visible as innovators than are men (Nyberg, 2009; Nählinder et al., 2010). 
This point can be illustrated by the observation that The Oxford Handbook of Innovation (Fagerberg et al., 2005) only mentions "women" four times, and never as innovators. There is a tendency to view women as actors at the receiving end of technology, or as users instead of as possible innovators (Cockburn and Ormrod, 1993). A somewhat limited and disparate discussion on innovation and gender does take place in other disciplines, however, including entrepreneurship (Ljunggren et al., 2010), economic geography (Blake and Hanson, 2005), political science (Lindberg, 2010) and among policy analysts. An attempt to explain the underrepresentation of women as innovators is found in the image of the inventor himself (sic!) - as a nerd. There are many women who cannot identify with this image (Nyberg, 2009).

As the social visibility of technology is higher in some (male-dominated) sectors (Nyberg, 2009), these sectors become the dominant ones (i.e. in the era of a resilient linear model). However, there is also the question of how industries are perceived. One example is the women-dominated textile industry, which is a technological industry without being regarded as such. An explanation for this could be found in the engineering profession, which is discussed by Nyberg (2009). She argues that the concept of innovation (or rather invention) is based on the engineering profession, which is strongly male-dominated. Note that women-dominated health care is a problem-solving activity, but it is seldom seen as innovative. Lindberg (2010) shows how male-dominated areas in the Swedish economy receive innovation funding more often than others. Almost 80 per cent of all projects that receive funding come from male-dominated sectors. Kvidal and Ljunggren (2010) discuss why innovation support tends to promote male-dominated sectors, and explore the possibility of changing the gender-pattern through promoting female-dominated sectors.

\section{The operationalisation of innovation}

Even if some definitions of innovation per se are inclusive, operationalisations of the concept are usually more restricted (cf. Acs et al., 2002; Green et al., 1995). In fact, it is common to use a patent, for example, as an operationalisation of innovation (Archibugi and Pianta, 1996). Comparing investment in R\&D with the number of applied patents makes it possible to measure output. However, counting patents implies that only the first of the two requirements of an innovation are captured because a patent is an invention rather than an innovation (i.e. the patent might end up in a drawer and never be realised as a product; it is never put into practice). Furthermore, these 
operationalisations underpin a gender bias.Weknow that among those seeking patents, men largely dominate (Nyberg, 2002). In Sweden, the geographical context of our study, only approximately 5 per cent of patent holders are female (Nyberg, 2009). Thus, even though the academic discussion has developed from the linear model, it still influences how innovations are operationalised. As explained by Godin (2006), this state of affairs exists because the linear model can be supported by statistics, while new models cannot. We argue that it is highly probable that the same type of gender labelling previously seen in entrepreneurship, self-employment and invention (Cohen and Jennings, 1995; Sundin, 2002; Ahl, 2004; Bruni et al., 2004; Brush et al., 2006, 2009; Tillmar, 2007; Sundin and Tillmar, 2010a, 2010b; Marlow and McAdam, 2012), also relates to innovation. In the field of entrepreneurship, there is an increasing awareness of gender bias, measured by the number of scholars focussing on the issue. This shift has, however, not yet taken place in the field of innovation studies, where the key concept is still seen as gender neutral (Ljunggren et al., 2010). Attempts have been made to redefine innovation, for example, by Blake and Hanson (2005), who take the geographical and social context of innovation into account.

The Oslo Manual (OECD, 2005) is an important tool for understanding innovation, and the CIS is internationally relied on by many scholars (cf. Fagerberg et al., 2012). However, while these studies are not left un-criticised, (cf. Salazar and Holbrook, 2004), the criticism is, with a few exceptions, not directly related to gender. As Amble (2010, p. 10) explains:

In principle, a seemingly gender-neutral word such as "innovation", put into practice through policy documents $[\ldots]$ can involve practices which are heavily gendered and context dependent without saying so. In the description of Norway today, innovation is claimed to be something masculine and perceived to be connected to something new, physical and technical, with the ability to compete in a globalised reality.

Amble (2010) argues that since the female workforce is employed to a very high extent in services and welfare, a suitable definition must take this into account, and not systematically exclude these activities from potentially innovative activities. In other words, the commercial aspects of the definition of innovation must be downplayed, and this can be done through replacing words such as commercialisation and economic value with utilisation and exploitation, thus disconnecting the concept of "innovation" from "pecuniary value". The author compares three definitions of innovation and concludes 
that words such as production, market and economic value are male-labelled, whereas a definition focussing on use and usability is more inclusive from a gender perspective. Other researchers have suggested the inclusion of gender by considering it as a dimension of innovation (Blake and Hanson, 2005). They argue that activities not ordinarily carried out as innovations should be regarded, as such, as an innovation, according to these authors, as women do not usually run auto repair shops.

Based on these previous studies, we suggest that distinguishing the definition of innovation from the operationalisation of innovation is an important stepping-stone to understanding the relationship between gender and innovation. That is to say, most definitions of innovation cover a wider range of innovations than the common operationalisations, which, in turn, are more gender-biased.

To conclude our review of the previous studies in this field, there are multiple and complex layers of gender-bias with respect to innovation. It is difficult to distinguish between the extent to which studies of innovativeness report gender-differences and the extent to which these differences actually exist.

\section{Empirical studies and analysis}

Before presenting our own survey data, we devote a section of this paper to presenting an analysis of the influential CIS study from a gender perspective.

\section{CIS from a gender perspective}

This analysis deals with $R Q 1$. Which industries dominate in previous studies of men and women's innovativeness? We have noted above that the industry sectors that are included in innovation surveys tend to be gender-biased. To illustrate this observation in more detail, we have analysed the industries that are covered in one of the most influential innovation surveys currently available,[2] the Swedish CIS 2008 (Statistics Sweden, 2009). There exist a number of innovation surveys such as the European CIS, and also the Canadian innovation survey, SIBS, and its USA equivalent, the BROS. However, one of these surveys is of particular interest - the CIS. The CIS is based upon the very influential Oslo Manual (OECD, 2005), which is a joint publication of OECD and Eurostat. What makes the CIS special is that it collects firm-level micro data longitudinally. Further, it was jointly launched in several (European Union) countries, which facilitates international comparisons (Eurostat, 2008). When the first CIS was launched in 1993, it was the first one ever to be internationally coordinated. For researchers, the CIS is very important and is often used for research purposes 
(Fagerberg et al., 2012). Because our survey, which is reported on below, was conducted in a Swedish context, we used the Swedish CIS (Statistics Sweden, 2009) as a source of information.

Statistics Sweden provided us with the number of men and women active in the economy according to industry. The RAMS database contains information on the Swedish labour force according to, inter alia, industry and gender. This has enabled us to compare the CIS selection of industries from a gender perspective. All 52 industries in the RAMS database were sorted into male-dominated industries (up to 40 per cent of all employees are female), gender-neutral industries and female-dominated industries (up to 40 per cent of all employees are male). The statistics are presented on an aggregated level, where the industries varied considerably in size. The smallest industry had 2,432 employees, while the largest industry was more than 191 times that number. The analysis of the horizontal segregation is thus hampered by the considerably different sizes of industries, a problem to which we will return.

Table I presents all 52 industries divided into horizontal segregation and inclusion in the CIS 2008. We can see that 30 of 52 industries were included in CIS, and the industries included are either male-dominated or gender-neutral[3]. We also note that very few industries (6 of 52) are female-dominated[4]. Although the CIS 2008 is a very valuable and widely used instrument for analysing innovation in Europe, it does not cover all industries; thus, we cannot generalise patterns of innovation based on a skewed selection of industries. We may also question why the CIS 2008 (Statistics Sweden, 2009) contains neither a discussion nor an explanation of the selection of industries that were covered in the survey.

Due to the remarkable differences in industry size, it is also important to mention the number of men and women working in the different industries.

Table II focusses on the number of employees working in industries according to gender-dominance and inclusion in the CIS 2008. The aggregated sums of the columns and the rows in Table II have been used to calculate the expected values of the other cells, given an equal distribution. In other words, the expected values are a mechanical calculation of the value of each cell assuming an equal distribution along the columns and rows. For example, 41.2 per cent of all employees are working in male-dominated sectors, and 67.6 per cent of all employees are working in sectors included in the CIS. Because the labour force consists of 4,515,371 employees, and 4,515,371 0.412866 
$0.676838 \_1,261,790$, we would expect approximately $1,261,790$ employees to work in the male-dominated sectors excluded in the CIS. However, as we saw in Table II, fewer people work in these sectors $(568,144)$. Further, the table shows that, for example, 1,296,099 employees were working in the 23 male-dominated industries included in the CIS, whereas 1,571,256 employees were working in the 6 female-dominated industries. When analysed in terms of the number of employees, Table II shows that male-dominated industries prevailed in the CIS 2008.

The distribution in Table II is not even remotely what would be expected assuming an equal distribution along columns and rows. In sum, these simple analyses show that the CIS 2008 has a strong gender-bias towards male-dominated sectors. One contributory factor to this state of affairs is that women are overrepresented in service sectors, both private and public; i.e. industries with a shorter tradition in innovation studies. As a consequence of this, women appear less innovative than they probably are, as they, to a lesser extent, work in sectors that are surveyed in more detail for innovation.

\section{The HCSFS study}

This section presents our empirical survey, its context and how it was conducted. First, it should be clarified that we refer to owner-managers as "entrepreneurs". For empirical reasons, we find this adequate to our current purposes, despite the theoretical distinctions between the concepts[5].

\section{Geographical and industrial context}

The HCSFS study was conducted in Scania, southern Sweden, in 2009. The survey was launched with the purpose of investigating the impact of policy changes on the health-care sector.Afurther discussion on the intended and unintended consequences of this is outside the scope of this paper, and we refer the reader to Sundin and Tillmar (2010a, 2010b).

\section{Population of firms included}

In terms of industrial context, the ISIC codes $86-88$, representing health-care and care services, were included in the present study. The entrepreneurs in the sample were active in the following six industries:

(1) housing and accommodation;

(2) primary health care;

(3) other public medical services;

(4) specialist care; 
(5) social work; and

(6) non-institutional care[6].

There were 2,318 health-care firms in the defined population in the region. As many as 1,638 of those companies had no employees, i.e. about 70 per cent were run by sole entrepreneurs. Because of this large group, we stratified a random sample, i.e. we interviewed 100 sole entrepreneurs and 100 entrepreneurs with employees. Interviews were conducted with 203 firms, of which 120 entrepreneurs were women, and 83 were men. Of the 120 women, 66 were sole entrepreneurs, while 33 of the 83 men were sole entrepreneurs. The HCSFS survey was responded to by the owner, and thus the sex of the owner could be extracted from the survey. When the firm had several owners, one owner responded to the survey. This implies that there might be a slight error in the distribution of gender in the survey, but we have no reason to assume a systematic error. Details of the non-response rate and the questionnaire are discussed in Nählinder et al. (2010). The sample was not stratified by the size of each firm, but a follow-up analysis has shown that the firm-size distribution in the sample does not differ from that of the population at large (ibid).

The entrepreneurs in the study

The sample covers an array of different care services, all of which are gender-labelled or dominated by women. Table III shows the industry and profession, and the number of men and women.

The proportion of male and female entrepreneurs in the sample is on a par with the proportion of men and women working in the industry as a whole (cf Nählinder et al., 2010, 2012). In Table III, we observe that a considerable number of "NEC" (not elsewhere classified) have chosen to start up a firm in care services. We further note that medical doctors are over-represented as entrepreneurs, and that assistant nurses are under-represented.

Questions in the survey

When formulating the questions on innovation, we adopted Fagerberg et al.'s (2005) definition rather than the every-day familiarity with the concept. In constructing the survey, we were inspired by the questions asked in the CIS, but we aimed at phrasing the questions in a more encompassing way. Consistent with the CIS's approach, we distinguish between product innovation and process innovation, but not primarily because we suspect gender differences in the actors' propensity to carry out product 
innovation and/or process innovation. Rather, we wanted to ask about innovations without explicitly using the word itself. We argue that this approach improves the validity of the study through measuring the extent of innovative behaviour rather than one's mere familiarity with the word itself. Table IV shows the questions and industries that were included.

First, we note that the CIS uses the terms production methods, supply methods and support methods, while the HCSFS uses the term working methods. We believe that using working methods is likely to turn respondents away from health-care and/or the public sector in line with Amble's (2010) argument. Both operationalisations explicitly mention the product (good/service), and, in the case of the CIS, its sale as well. Both operationalisations make reference, to different extents, to the commercialisation (of goods/services) and pose the question by using business terminology.

With regard to the term innovation, the CIS mentions the word in the heading, in contrast to the HCSFS, which does not. Therefore, we argue that the HCSFS uses more gender-neutral operationalisations than the CIS[7].

\section{Methodology and analysis}

Based on the HCSFS sample, we created two groups, men and women, to compare their innovativeness. We report on the proportion of men and women who created innovations during the period, and the proportion of men and women who carried out product or process innovations. We also performed one-way analysis of variance (ANOVA) tests which are univariate non-parametric tests to identify statistically significant differences between the two groups of entrepreneurs. Such tests are appropriate when analysing subsamples with a varying number of respondents. The tests incorporate less rigorous assumptions than parametric tests because they are not dependent on assumptions of the precise form of distribution of the sampled population. Consequently, they can be used on a variety of measurement scales.

\section{Findings}

We have used univariate non-parametric tests, as described above, to test whether we could identify statistically significant differences between men and women in our study of a female-labelled sector with relatively gender-neutral operationalisations. When we analysed whether the firms made any innovations during the period, we included both of the questions presented above, i.e. whether the entrepreneurs carried out either a product innovation (a new or improved good or service) or a process innovation (a new 
or improved method of producing goods or services) or both. We also used innovativeness as the dependent variable and gender as a factor in the one-way ANOVA. The results are presented in Table V.

The first important observation is that the proportion of innovative firms is very high, regardless of the gender of the entrepreneur. Thus, it is possible that the inclusive operationalisations used here capture more innovations carried out by both women and men than the CIS does. We further observe that there are small differences in innovativeness between men and women, and that these differences are not statistically significant. The significance value is 0.412 , i.e. not statistically significant. In other words, when treated as statistical categories, there are no differences in innovativeness between men and women in the HCSFS.

As a second step in our analysis, we looked closer into the type of innovation carried out by the entrepreneurs. Our analysis is presented in Table VI.

As Table VI shows, we find that women appear slightly more inclined towards process innovation, whereas men engage in product innovation somewhat more. However, neither of these differences is statistically significant. To come to this conclusion, two different one-way ANOVAs were performed, both with gender as a factor. In the first ANOVA, product innovation was considered to be the dependent variable and, in the second ANOVA, process innovation was considered to be the dependent variable. The first ANOVA had a significance level of 0.394, and the second had 0.915. In other words, not even when innovation is broken down into product innovation and process innovation do we find any statistical differences between men and women in the HCSFS study.

The analysis thus contributes to the present knowledge on innovativeness among men and women by suggesting that there are no significant differences between men and women if the study itself is not gender-biased. However, the survey data reveal limited information about the underlying motivation to innovate. Furthermore, a possible explanation as to why the respondents are so innovative could be that they are in a developing industry. Thus, we suggest that the gender-aware approach to innovation used in the HCSFS study has revealed previously invisible innovations in the health-care sector, in general, and among women, in particular.

\section{Discussion}

The aims of this paper are: 
- to discuss the theory of gender bias in innovation studies;

- to illustrate the gender bias of innovation studies by using empirical means; and

- to suggest what is needed to reduce this bias.

We fulfil these aims by answering the three research questions:

$R Q 1$. Which industries have dominated in previous studies of men's and women's innovativeness?

$R Q 2$. What are the gendered consequences of previous operationalisations of innovation?

$R Q 3$. Does a gender-aware operationalisation combined with a focus on femalelabelled industries still indicate significant differences between men's and women's innovativeness?

These three research questions are discussed in turn.

The first point concerns the industries that have been studied in previous research on men and women's innovation. The emerging literature on gender and innovation has shown how innovation is supported and investigated in male-dominated sectors. Our analysis of the horizontal segregation in the Swedish CIS 2008 shows how male-dominated industries prevail in the selection of industries that were surveyed. The (gendered) selection of industries is taken for granted to the point where it is not even discussed in the report (Statistics Sweden, 2009).

The concept of "innovation" was developed within the realm of manufacturing, which, by tradition, is male-dominated. This creates a pattern of assumptions where the operationalisations of innovation are closely linked to these industries. The assumptions are strengthened by layers of gender labelling - of the occupations, the industries and of the activities per se. Innovation has become a male activity, which is reflected in policy and funding (Lindberg, 2010). Changing this underlying, yet strong, pattern requires an awareness of the phenomenon and its consequences. The gender-bias in the industries that were investigated needs to be given further credence. An important step towards this goal would be to systematically map the gendered pattern of the industries that are usually included in innovation surveys (other than the CIS), and to question the selection of particular industries found therein.

The second research question concerns the gendered consequences of previous operationalisations of innovation. Both previous research and our CIS analysis have 
shown that innovation, just as entrepreneurship, is still gender-labelled as "male". If we are to investigate the phenomenon of innovation, rather than merely the perception of the word, we may have to avoid using the word itself. In re-expressing the concept of "innovation", i.e. in operationalising it, we also need to be aware of the gender-label invoked by other words. Amble (2010) discusses the gender-labelling of innovation and points out that some words associated with innovation, such as production, market and economic value, do not contribute to the perception of female-labelled activities as being innovative. CIS 2008 includes the words innovation, production methods, supply methods and support methods, all of which, assuming the veracity of Amble's argument, are male-labelled. In formulating the questions on innovation in the HCSFS, we have partly succeeded in operationalising innovation in gender-neutral terms, as seen in Table IV. However, as the questions are still formulated by using business terminology, the HCSFS also includes some male-labelled words. The operationalisation trap is ominous as well as inevitable. Notwithstanding this, the HCSFS has taken a big step towards a gender-neutral goal. Arguably, this operationalisation is likely to have captured a wider range of innovations from both men and women.

The third research question we address in this study concerns the differences between males and females regarding innovativeness in a relatively gender-neutral study. We have seen that the somewhat sparse research on innovation and gender does reveal gender differences. However, the HCSFS does not actually present any statistically significant differences between men and women regarding innovativeness. A plausible explanation is that we have taken into account the dimensions of gendering identified through the literature review. We suggest that this is the main reason why we do not find differences in innovativeness between men and women.

\section{Theoretical and methodological conclusions}

The findings that arise from addressing the three research questions are interlinked. Together, they give us several pieces of the puzzle of how innovation is gendered in research, policy and practice. We have chosen to express our theoretical and methodological categories as three dimensions, which we suggest should be considered in future studies. Those dimensions are foundational to our analysis:

- gendered operationalisations;

- gender-labelling of the sectors that are investigated; and

- the gender/sex of innovator. 
This model is used to explain the invisibility of women's innovativeness in previous studies. Thereafter, we suggest a model to enable gender neutrality in future innovation studies.

Dimension 1: gendered operationalisation. We found that the operationalisation of innovation may be gender-biased to differing degrees. HCSFS uses a more gender-neutral operationalisation of innovation than studies that are still heavily influenced by the linear model, like, for example, the CIS in Europe, BROS in the USA or SIBS in Canada. Our contention is that the (more) gender-aware operationalisation of innovation used in our survey has had a strong positive impact on the range of entrepreneurs who identify themselves as innovative. In consequence, we identify a very high level of innovativeness among both male and female entrepreneurs. Our operationalisation of innovation has contributed to making many previously invisible innovations visible, which confirms our observations from previous studies on innovativeness. The visibility of innovation is important, not least because it is more difficult to support invisible innovation. The relatively gender-neutral operationalisation of innovation that was applied in the HCSFS survey is a prerequisite for understanding why - in contrast to previous studies - there are no statistically significant differences between men and women in our analysis. Thus, we contend that there is empirical support for using not only inclusive definitions but also inclusive operationalisations of innovation.

Dimension 2: gender labelling of the sectors that are investigated. The sectors that are investigated may be gender-labelled. HCSFS covers female-labelled sectors, but it is puzzling why this has been done so infrequently. The lack of gender-awareness in previous studies can be explained by the fact that the CIS is perceived and used by researchers and policymakers as the definitive tool for measuring innovations (cf. Schubert, 2010). A consequence of this is a focus on male-labelled sectors. Furthermore, the general understanding that innovations are perceived as tangible products implies a focus on certain sectors. The high innovation level in the HCSFS is a clear indication that this type of sector should also be included in surveys of innovation, such as the CIS. The exclusion of the health-care industry from Sweden's CIS 2008 reproduces a skewed understanding of innovation, and reinforces the vicious circle in which employees in certain industries do not see their creative problem-solving as innovative. A fundamental issue from a gender perspective is 
that the male labelling of innovation makes the phenomenon invisible among employees in female-labelled industries.

Dimension 3: gender/sex of innovator. Our findings from the HCSFS appear to be in contrast to previous studies (Ljunggren, 2002; Nyberg, 2009), as we do not find a statistically significant relationship between the gender of an innovator and innovativeness. What appears to be a disproportionate number of innovative women in the HCSFS, appears to be less strange when the operationalisation (Dimension 1) and the sectors that are chosen (Dimension 2) are taken into consideration. Based on the HCSFS analysis, we suggest that women and men may be equally innovative, but that the visibility of innovation is hampered in the three dimensions, and if Dimension 1 and Dimension 2 are properly considered, the third dimension may prove to be of less significance. Nonetheless, to further develop a theory of gender and innovation, it is still relevant to generate data that distinguish between men as innovators and women as innovators. Because both men and women are socialised into a gendered society, differences in innovativeness in some future studies would by no means be surprising. Notwithstanding this, as Nyberg (2009) argues, invisibility is also related to the gender of the innovator.

The three dimensions are interrelated in the model below[8]. All three should be taken into account simultaneously to understand the complex issue of innovation and gender. Primarily, men are visible as innovators with a gender-biased operationalisation of innovation. When the gendering of operationalisation enters the picture (i.e. the right side of Figure 1), many more innovations, from both male and female innovators, are visible. We observed this in the HCSFS study. In short, the way we measure innovation will have a great impact upon the (number of) visible innovations of men and women.

The discussion here shows the need for further studies and theory development of both a quantitative and qualitative nature. The model we present above should be scrutinised and further elaborated. Of particular importance is the further investigation of the empty cells in the figure. Conducting a gender-neutral study of innovation would also be valuable in studies of male gender-labelled sectors. In fact, the formulation of the HCSFS survey questions has probably had a positive impact on the number of innovations reported by both men and women, presumably eliciting more, otherwise invisible, innovations. A similar discussion could of course be based on other 
intersectional perspectives, incorporating such issues as class and/or ethnic minorities into the analysis.

Specifically, we suggest that a gender-neutral operationalisation of innovation should:

- exclude references that make operationalisation difficult to apply to welfare or public-sector activities (such as the explicit reference to commercialisation);

- exclude the word innovation, as the concept that is associated with this word is male-gendered;

- exclude references, including words, that are primarily used within manufacturing-, engineering- or high-tech contexts, for example, patents; and

- use a typology of innovation that clearly includes innovations other than goods and technological process innovations. One way is to use the extended taxonomy of "product innovation" and "process innovation" (Edquist et al., 2001; Nählinder, 2005), as it includes both organisational and service innovations.

\section{Implications for policy and practice}

The implications of these findings for policy and practice are profound in the sense that potentially successful innovations may come from other sectors and actors than previously assumed. This is of particular importance when allocating resources and designing support programmes. Are female gender-labelled sectors, in particular, those with steady growth, such as the health-care sector, perhaps the most important and the most promising when it comes to innovations? Sectors commonly understood as un-innovative might, thus, quite the contrary to common thinking, be very innovative.

There is a need to re-think how innovation studies are conducted, and on which sectors they are conducted. Some questions that arise from our findings are: Are previous studies on innovation gender-biased, conducted with a male norm perspective and a male-orientated definition of innovation? How should we understand the connection between entrepreneurship and innovativeness? How does the gender labelling of a sector or industry affect the innovativeness of men and women in that sector/industry?

Lindberg (2010) concludes that almost 80 per cent of the innovation systems and 
clusters that received financial support from national and regional policy programmes involved industries dominated by men. She finds in her study that sectors employing many women are marginalised when the clusters and innovation systems are promoted. Lindberg stresses the need for operationalising innovation in new ways. In this paper, we argue that it is of importance to rethink where and how innovation is studied. This is especially important as research and policy should be closely linked. If our understanding of innovation continues to follow the linear model of innovation, as a sequential process originating from basic research, only certain types of industries will be deemed important; industries that are dominated by men. This is ironic, because we know that future growth industries, such as the health-care industry, are currently dominated by women and, furthermore, dominated by services and processes. To create space for industries such as the health-care industry in innovation policy, the measurement and common understanding of innovation has to be adjusted.

Throughout the paper, we have shown that the way in which questions are formulated in surveys, and how industries are selected for inclusion in said surveys, have gender implications. We strongly argue that not only must the selection of industries be extended to include more (and female-dominated) sectors, but questions must also be asked in a gender-neutral manner. If surveys become gender-aware, we will also gain a more nuanced understanding of what innovation incorporates, and what may strengthen innovation in the future. There may also be other obstacles to innovation, such as a lack of non-monetary resources and self-esteem (Nählinder, 2010), which may hamper the realisation of innovation. In conclusion, if we do not survey the occurrence and nature of innovation in these sectors properly, important factors will be missed.

\section{Notes}

1. The health-care sectors are of great importance when sustainable growth is targeted in the Western context. According to the World Bank, 10 and 17 per cent of gross domestic product is used for health care in the European Union and the United States, respectively (www.data.worldbank.org).

2. http://epp.eurostat.ec.europa.eu/portal/page/portal/microdata/cis 
3. That is to say, an industry is male-dominated if more than 60 per cent are male, and gender neutral if the percentage of males and females are within the frame of 60-40 per cent. Statistics Sweden contains information on the Swedish labour force, i.e. men 2,364,148 and women $2,151,223$. In total, women thus constitute 47.6 per cent of the Swedish labour force.

4. This is a well-known phenomenon which is related to the breakdown of industries, where male-dominated industries are typically described on a finer level than female-dominated industries, which are often described on a more aggregated level.

5. This is in line with mainstream entrepreneurship theory. When working on the sample (further explained below), we did not possess any criteria for examining whether the owner-manager was acting in an entrepreneurial manner. An entrepreneur, relying on Schumpeter's (1934/1994) definition, is a person who, at least, does one of the following five things: introduces new goods to the market; introduces new methods of production; opens up a new market; exploits a new source of supply of raw material or half-manufactured goods; or carries out new organisation of any industry, such as the creation of a monopoly or the breaking up of a monopoly. Generally speaking, most owner-managers in the health-care sector carry out one or several of the activities above, as they are acting in a market which is in transition - as a monopoly is opened up for private actors. We thereby argue that they fulfil the definition of an entrepreneur. Furthermore, an argument for using the term entrepreneur and not owner-manager is in agreement with the main argument of the paper - the health-care sector deliberately needs to reflect on concepts like "entrepreneur", "entrepreneurship" and "innovation".

6. Some industries were excluded: dentists and dental hygienists, medical laboratories, children's care, operation of refugee camps and humanitarian services and physiotherapy services. The ISIC physiotherapy services code covers quite a large group of firms, with many run by sole entrepreneurs.

7. A methodological problem that was identified - once our analysis was complete - concerns the length of the time for which the firm reports to be innovative so as to actually qualify as innovative. In the CIS, it is clearly stated that it is a three-year time period, which is under scrutiny. The HCSFS, however, vaguely refers to the last few years. It is not possible with certainty to interpret the length of the time period understood by a "few years", but we assume that the respondents interpreted this as approximately three years, making the time-length roughly equivalent of the CIS.

8. This model, although with a less developed discussion, we previously presented in a 
book-chapter (Nählinder et al., 2012).

\section{References}

Acs, Z.J., Anselin, L. and Varga, A. (2002), "Patents and innovation counts as measures of regional production of new knowledge", Research Policy, Vol. 31 No. 7, pp. 1069-1085.

Ahl, H. (2004), The Scientific Reproduction of Gender Inequality: A Discourse Analysis of Research Texts on Women's Entrepreneurship, Liber, Stockholm.

Alsos, G., Ljunggren, E. and Hytti, U. (2013), "Gender and innovation: state of the art and research agenda", International Journal of Gender and Entrepreneurship, Vol. 5 No. 3, pp. 236-256.

Alvesson, M. and Sköldberg, K. (2000), Reflexive Methodology: New Vistas for Qualitative Research, Sage, London.

Amble, N. (2010), "Regional innovation and the 'catch' of women", paper presented at the Conference Gender Work and Organization, 21-23 June, Keele University, Keele.

Archibugi, D. and Pianta, M. (1996), "Measuring technological change through patents and innovation surveys", Technovation, Vol. 16 No. 9, pp. 451-468.

Barras, R. (1986), “Towards a theory of innovation in services”, Research Policy, Vol. 15 No. 4, pp. 161-173.

Blake, M.K. and Hanson, S. (2005), "Rethinking innovation: context and gender", Environment and Planning A, Vol. 37 No. 4, pp. 681-701.

Bruni, A., Gherardi, S. and Poggio, B. (2004), "Doing gender, doing entrepreneurship: an ethnographic account of intertwined practices", Gender, Work and Organization, Vol. 11 No. 4, pp. 406-429.

Brush, C.G., Carter, N.M., Gatewood, E.J., Greene, P.G. and Hart, M.M. (2006), Growth Oriented Women Entrepreneurs and their Businesses, Edward Elgar, Cheltenham.

Brush, C.G., de Bruin, A. and Welter, F. (2009), “A gender-aware framework for women’s entrepreneurship", International Journal of Gender and Entrepreneurship, Vol. 1 No. 1, pp. 8-24.

Cockburn, C. and Ormrod, S. (1993), Gender and Technology in the Making, Sage, London. Cohen, L. and Jennings, P. (1995), "Invisible entrepreneurs: issues, contexts and approaches in researching and supporting enterprising women - part 1", Business, Growth and Profitability, Vol. 1 No. 4, pp. 339-351.

Earl, L. (2002), Innovation and change in the public sector. A seeming oxymoron, Statistics Canada. Edquist, C., Hommen, L. and McKelvey, M. (2001), Innovation and Employment: Process Versus 
Product Innovation, Edward Elgar, Cheltenham.

Elg, M. and Kollberg, B. (2009), “Alternative arguments and directions for studying performance measurements", Total Quality Management and Business Excellence, Vol. 20 No. 4, pp. $409-421$.

Eurostat (2008), Science, Technology and Innovation in Europe, Eurostat statistical books. Fagerberg, J., Mowery, D. and Nelson, R. (2005), Oxford Handbook of Innovation, Oxford University Press, Oxford.

Fagerberg, J., Mowery, D.C. and Nightingale, P. (2012), “Introduction: the heterogeneity of innovation - evidence from the Community Innovation Surveys", Industrial and Corporate Change, Vol. 21 No. 5, pp. 1175-1180.

Fogelberg, E. (2013), “A gender perspective as a trigger and facilitator of innovation”, International Journal of Gender and Entrepreneurship, Vol. 6 No. 2.

Gallouj, F. and Weinstein, O. (1997), "Innovation in Services", Research Policy, Vol. 26 Nos 4/5, pp. 537-556.

Godin, B. (2006), "The linear model of innovation: the historical construction of an analytic framework”, Science, Technology \& Human Values, Vol. 31 No. 6, pp. 631-667.

Green, S.G., Gavin, M.B. and Aiman-Smith, L. (1995), “Assessing a multidimensional measure of radical technological innovation", IEEE Transactions On Engineering Management, Vol. 42 No. 3, pp. 203-214.

Kanter, R.M. (2000), "When a thousand flowers bloom: structural, collective and social conditions for innovation in organization'”, in Swedberg, R. (Ed.), Entrepreneurship, Oxford University Press, Oxford, pp. 167-210.

Kelley, D.J., Singer, S. and Herrington, M. (2012), The Global Entrepreneurship Monitor, Global Report, Babson College, Wellesley, MA.

Kline, S.J. (1985), "Innovation is not a linear process", Research Management, Vol. 28 No. 2 , pp. 36-45.

Kline, S. and Rosenberg, N. (1986), “An overview of innovation”, in Landau, R. and Rosenberg, N. (Eds), The Positive Sum Strategy: Harnessing Technology for Economic Growth, National Academy Press, Washington, DC, pp. 275-304.

Kvidal, T. and Ljunggren, E. (2010), “Implementing 'a gender perspective' in an innovation program: more innovation or ambivalence and uncertainty?", paper presented at the Conference Gender, Work and Organization, 21-23 June, Keele University, Keele. Lindberg, M. (2010), “Samverkansnätverk för innovation: en interaktiv och genusvetenskaplig 
utmaning av innovationspolitik och innovationsforskning”, Dissertation, Luleå University of Technology, Luleå.

Ljunggren, E. (2002), “Entreprenörskap og kjønn: en kunnskapsreise mellom to perspektiver: fra individ til relasjon", Studier i företagsekonomi, Serie B, Umeå University,

Umea, No. 48.

Ljunggren, E., Alsos, G., Amble, N., Ervik, R., Kvidal, T. and Wiik, R. (2010), Gender and Innovation: Learning from Regional VRI-projects, NF-report 2/2010, Nordland Research Institute, Bodö.

Lundvall, B.A. (1988), "Innovation as an interactive process: from user producer interaction to national system of innovation”, in Dosi, G., Freeman, C., Silverberg, G. and Soete, L. (Eds), Technical Change and Economic Theory, Printer, London, pp. 349-369.

Marlow, S. and McAdam, M. (2012), “Analyzing the influence of gender upon high-technology venturing within the context of business incubation", Entrepreneurship, Theory and Practice, Vol. 36 No. 4, pp. 655-676.

Meyers, S. and Marquis, D.G. (1969), Successful Industrial Innovations: A Study of Factors Underlying Innovation in Selected Firms, NSF 69-17, National Science Foundation, Washington, DC.

Miles, I. (2005), "Innovation in Services", in Fagerberg, J., Mowery, D. and Nelson, R. (Eds), The Oxford Handbook of Innovation, Oxford University Press, Oxford.

Mulgan, G. (2007), "Ready or not? Taking innovation in the public sector seriously", Provocation, 3 April.

Nählinder, J. (2005), Innovation and employment in Services: The case of Knowledge Intensive Business Services in Sweden, Linköping University, Linköping.

Nählinder, J. (2010), "Where are all the female innovators? Nurses as innovators in a public sector innovation project", Journal of Technology Management and Innovation, Vol. 5 No. 1,

pp. 13-29.

Nählinder, J., Tillmar, M. and Wigren, C. (2010), "Innovativeness among entrepreneurs in a female gender labelled sector", paper presented at the Conference Gender Work and Organization, 21-23 June, Keele University, Keele.

Nählinder, J., Tillmar, M. and Wigren-Kristoferson, C. (2012), “Are female and male entrepreneurs equally innovative? Reducing the gender bias of operationalization's and industries", in Andersson, S., Berglund, K. and Sundin, E., Gender and Innovation, Vinnova, Stockholm. Nyberg, A.C. (2002), “Genus och innovation - om kvinnors formande av teknik och samhälle,” 
Forskningsrapport TRITA-IEO-R 2006:16, Institutionen för Industriell Ekonomi och

Organisation, Kungliga Tekniska Högskolan, Stockholm.

Nyberg, A.C. (2009), “Making ideas matter: gender, technology and women’s invention”,

Dissertation, Department of Human Work Sciences Division of Gender and Innovation,

Luleå University, Lulea.

OECD (1997), The Measurement of Scientific and Technological Activities Proposed Guidelines for

Collecting and Interpreting Technological Innovation Data: Oslo Manual, OECD,

Luxemburg.

OECD (2005), The Measurement of Scientific and Technological Activities Oslo Manual: Guidelines

for Collecting and Interpreting Innovation Data, OECD, Luxemburg.

Pettersson, K. (2007), "Men and male as the norm? A gender perspective on innovation policies in

Denmark, Finland and Sweden”, Report 4, Nordregio.

Potts, J. and Kastelle, T. (2010), “Public sector innovation research; what is next?", Innovation:

Management, Policy and Practice, Vol. 12 No. 2, pp. 122-137.

Price, W.J. and Bass, L.W. (1969), "Scientific research and the innovative process", Science,

Vol. 164 No. 3881, pp. 802-806.

Rothwell, R. (1992), “Successful industrial innovation: critical factors for the 1990s", $R \& D$

Management, Vol. 22 No. 3, pp. 221-239.

Salazar, M. and Holbrook, A. (2004), “A debate on innovation surveys” Science and Public Policy,

Vol. 31 No. 4, pp. 254-266.

Schmookler, J. (1966), Invention and Economic Growth, Harvard University Press, Cambridge, MA.

Schubert, T. (2010), "Marketing and organizational innovations in entrepreneurial innovation processes and their relation to market structure and firm characteristics", Review of Industrial Organization, Vol. 36 No. 2, pp. 189-212.

Schumpeter, J. (1934/1994), “The theory of economic development”, in Swedberg, R. (Ed.),

Schumpeter: Om skapande förstörelse och entreprenörskap, City University Press,

Ratioklassiker.

Statistics Sweden (2009), Innovationsverksamhet i svenska företag 2006-2008 (Swedish CIS),

Statistics Sweden (SEB), Stockholm.

Statistics Sweden (2011), "RAMS (Registerbaserad arbetsmarknadsstatistik)", available at: www.scb.se.

Sundin, E. (2002), "Företagandets manliga prägling: orsaker och konsekvenser”, in Holmquist, C. 
and Sundin, E. (Eds), Företagerskan: Om kvinnor och entreprenörskap, SNS Förlag,

Stockholm

Sundin, E. and Tillmar, M. (2010a), Varför ska kvinnor starta företag inom vård- och omsorg?,

Tillväxtverkets skriftserie.

Sundin, E. and Tillmar, M. (2010b), “The masculinization of the elderly care sector: local-level studies of public sector outsourcing”, International Journal of Gender and

Entrepreneurship, Vol. 2 No. 1, pp. 49-67.

Tillmar, M. (2007), “Gendered small business assistance: lessons from a Swedish project”, Journal of European Industrial Training, Vol. 31 No. 2, pp. 84-99.

Utbult, M. (2007), Måste innovationer vara av metall? Att tänka om och skapa nytt i kommuner,

landsting och regioner, SKL, Trygghetsfonden, Vinnova, Stockholm.

von Hippel, E. (1988), The Source of Innovation, Oxford University Press, New York, NY.

Windrum, P. and Koch, P. (2008), Innovation in Public Sector Services, Edward Elgar, Cheltenham.

\section{Further reading}

World Bank, available at: http://data.worldbank.org/indicator/SH.XPD.TOTL.ZS/countries

\section{Corresponding author}

Malin Tillmar can be contacted at: Malin.tillmar@liu.se

\section{Figures}

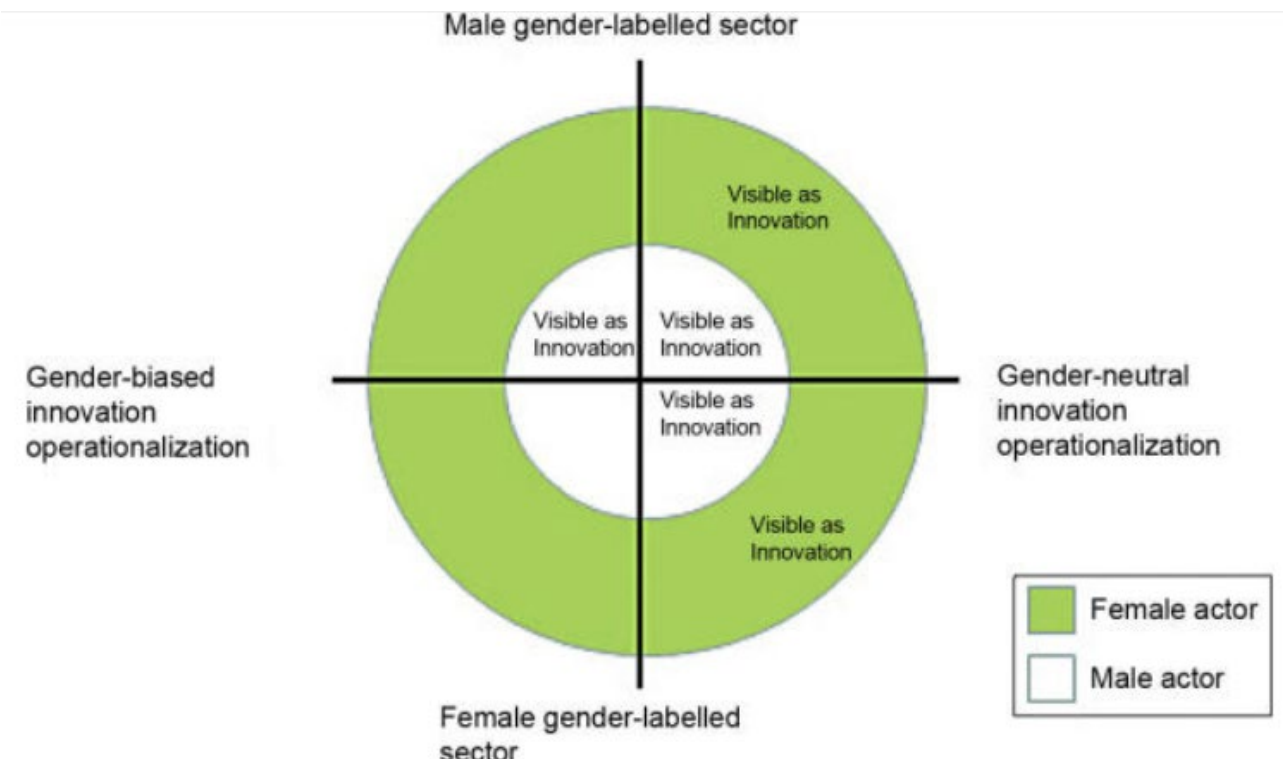

Tables 


\begin{tabular}{lllll}
\hline & $\begin{array}{l}\text { Male } \\
\text { dominated }\end{array}$ & $\begin{array}{l}\text { Gender } \\
\text { neutral }\end{array}$ & $\begin{array}{l}\text { Female } \\
\text { dominated }\end{array}$ & $\begin{array}{l}\text { Number of } \\
\text { industries }\end{array}$ \\
\hline $\begin{array}{l}\text { Included in } \\
\text { CIS }\end{array}$ & 24 & 6 & - & 30 \\
$\begin{array}{l}\text { Partly } \\
\text { included }\end{array}$ & - & 1 & - & 1 \\
$\begin{array}{l}\text { Excluded in } \\
\text { CIS }\end{array}$ & 5 & 10 & 6 & 21 \\
$\begin{array}{l}\text { Total number } \\
\text { of industries }\end{array}$ & 29 & 17 & 6 & 52 \\
\hline
\end{tabular}

Table 1. The industries (ISIC rev 4) of the Swedish economy divided according to horizontal segregation and in relation to the CIS 2008. Sources: Statistics Sweden RAMS database 2011 and Statistics Sweden (2009).

\begin{tabular}{lllll}
\hline & $\begin{array}{l}\text { Male- } \\
\text { dominated }\end{array}$ & $\begin{array}{l}\text { Gender- } \\
\text { neutral }\end{array}$ & $\begin{array}{l}\text { Female- } \\
\text { dominated }\end{array}$ & $\begin{array}{l}\text { Number of } \\
\text { employees }\end{array}$ \\
\hline $\begin{array}{l}\text { Included in } \\
\text { CIS }\end{array}$ & $1,296,099$ & 112,311 & 0 & $1,408,410$ \\
$\begin{array}{l}\text { Partly } \\
\text { included }\end{array}$ & 0 & 50,788 & 0 & 50,788 \\
$\begin{array}{l}\text { Excluded in } \\
\text { CIS }\end{array}$ & 568,144 & 916,773 & $1,571,256$ & $3,056,173$ \\
$\begin{array}{l}\text { Total number } \\
\text { of employees }\end{array}$ & $1,864,243$ & $1,079,872$ & $1,571,256$ & $4,515,371$ \\
\hline
\end{tabular}

Table 2. The actual number of employees in Sweden according to industry (ISIC rev 4), horizontal segregation and relation to the CIS 2008. Sources: Statistics Sweden RAMS database 2011 and Statistics Sweden (2009).

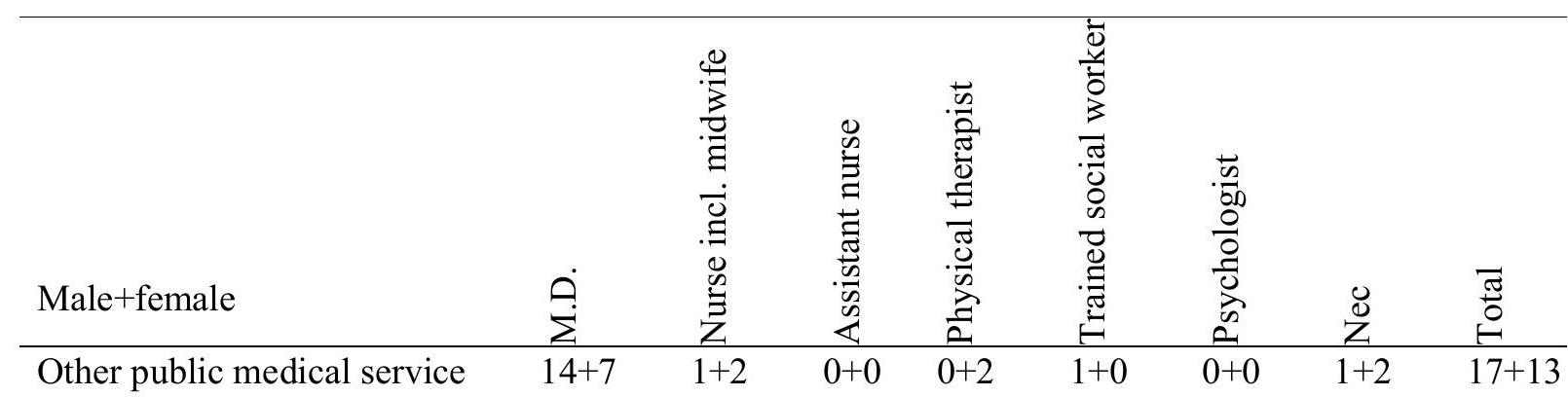




$\begin{array}{lllllllll}\text { Other non-institutional care } & 3+0 & 0+6 & 0+3 & 1+5 & 3+4 & 6+16 & 11+28 & 24+62 \\ \text { Housing and accommodation } & 0+0 & 0+4 & 1+0 & 0+0 & 1+0 & 1+0 & 10+5 & 13+9 \\ \text { Primary health care } & 2+2 & 0+0 & 0+0 & 0+0 & 0+0 & 0+0 & 0+1 & 2+3 \\ \text { Specialist care } & 8+3 & 0+2 & 0+0 & 0+0 & 0+0 & 0+0 & 3+4 & 11+9 \\ \text { Social work } & 0+0 & 0+2 & 0+0 & 0+0 & 1+4 & 1+15 & 10+0 & 12+21 \\ \text { Total } & 27+12 & 1+15 & 1+3 & 1+7 & 6+8 & 8+16 & 35+55 & 79+11 \\ & & & & & & & & 7\end{array}$

Table 4. Industry and profession, and the number of men + women

\begin{tabular}{|c|c|c|}
\hline & 2008 & HCSFS \\
\hline $\begin{array}{l}\text { Sectors (ISIC rev } 4 \text { for } \\
\text { CIS; ISIC rev } 3 \text { for } \\
\text { HCSFS) }\end{array}$ & $\begin{array}{l}5-9,10-33,35-39,46,49-53,58,61-63 \text {, } \\
64-66,71,72 .\end{array}$ & $\begin{array}{l}86212,86909,87100,87201,87202, \\
87203,87301,87901,87902,86211, \\
86102,86221,86222,88101,88102, \\
88992,88993\end{array}$ \\
\hline $\begin{array}{l}\text { Question(s) regarding } \\
\text { product innovation }\end{array}$ & $\begin{array}{l}\text { During the 3-year period [1 January } \\
2006-31 \text { December 2008] did the } \\
\text { business introduce: } \\
\text { a) New or significantly improved } \\
\text { goods? Exclude the simple resale of } \\
\text { goods purchased from other businesses } \\
\text { and changes of a solely aesthetic nature. } \\
\text { b) New or significantly improved } \\
\text { services? }\end{array}$ & $\begin{array}{l}\text { Of the products you are selling, are there } \\
\text { any goods/services that you have } \\
\text { developed or developed further during } \\
\text { the last few years? }\end{array}$ \\
\hline $\begin{array}{l}\text { Question(s) regarding } \\
\text { process innovation }\end{array}$ & $\begin{array}{l}\text { During the 3-year period [1 January } \\
2006 \text { - } 31 \text { December 2008] did the } \\
\text { business introduce new or significantly } \\
\text { improved processes for producing or } \\
\text { supplying goods or services? } \\
\text { Between 2006-2008, did your firm } \\
\text { introduce... } \\
\text { - New or considerably } \\
\text { improved production } \\
\text { methods? } \\
\text { New or considerably } \\
\text { improved supply methods? } \\
\text { New or considerably } \\
\text { improved support activities } \\
\text { for the company's processes? }\end{array}$ & $\begin{array}{l}\text { Have you, during the last few years, } \\
\text { developed new working methods in } \\
\text { your company to produce } \\
\text { goods/services? }\end{array}$ \\
\hline
\end{tabular}

Table 5. Comparison of the operationalization of product and process innovation in CIS and HCSFS. 


\begin{tabular}{llll}
\hline Has the firm made any innovations? & Yes & F & p \\
\hline Men & $81 \%(67)$ & $\mathrm{F}(1,202)=0,675$ & 0,412 \\
Women & $76 \%(91)$ & & \\
\hline
\end{tabular}

Table 6. Proportion of men and women who made innovations during the period under investigation. (Source: HCSFS).

\begin{tabular}{|c|c|c|c|c|c|c|}
\hline $\begin{array}{l}\text { Percentage } \\
\text { of firms } \\
\text { which made }\end{array}$ & $\begin{array}{l}\text { Product } \\
\text { innovation }\end{array}$ & $\mathrm{F}$ & $\mathrm{p}$ & $\begin{array}{l}\text { Process } \\
\text { innovation }\end{array}$ & $\mathrm{F}$ & $\mathrm{p}$ \\
\hline \multirow[t]{2}{*}{ Men } & $64 \%$ & $\mathrm{~F}(1,202)$ & 0,394 & $65 \%$ & $\mathrm{~F}(1,202)$ & 0,915 \\
\hline & & $=0,731$ & & & $=0,011$ & \\
\hline Women & $60 \%$ & & & $68 \%$ & & \\
\hline Total & $62 \%$ & & & $67 \%$ & & \\
\hline
\end{tabular}

Table 7. Proportion of men and women who have carried out product or process innovation. (Source: HCSFS). 